\title{
Stock volatility, return jumps and uncertainty shocks during the Great Depression
}

\author{
GABRIEL P. MATHY \\ American University
}

\begin{abstract}
There are a multitude of explanations for the depth and length of the Great Depression, of which uncertainty has been proposed as one possible explanation (Romer I990). The I930s not only saw extreme declines in output and prices, but stock volatility was also at record highs (Schwert 1989). This high stock volatility was generated by a series of discontinuous jumps as news about uncertainty arrived regularly during the I930s, as shown by applying the Barndorff-Nielsen and Shephard (2006) test for jumps in a time-series. To provide a more historical narrative for these jumps, I outline some key events during the Great Depression that generated a sense of uncertainty for businesses and households which occurred contemporaneously to these extreme jumps. While much of the literature has placed Roosevelt's New Deal as a primary source of uncertainty, I do not find much evidence for this hypothesis, and instead find that banking crises, the breakdown of the gold standard, popular unrest and uncertainty related to the brewing war in Europe were primarily responsible for both jumps in returns and the uncertainty of the r93os.
\end{abstract}

Keywords: uncertainty shocks, stock volatility, jump-diffusion process, Great Depression

JEL classification: $\mathrm{N}_{12}, \mathrm{~N}_{22}, \mathrm{G}_{14}$

The Great Depression was a disastrous period in American history, with record output declines, record unemployment and economic weakness which persisted for over a decade. With the benefit of hindsight it may seem clear that the Great Depression was a temporary aberration for an American economy which has seen persistent growth throughout its recorded economic history. Those that lived through the Depression, however, experienced unprecedented uncertainty shocks, including a major banking and financial crisis, uncertain monetary policies, an uncertain international monetary system based on the gold standard, major government policy changes and the uncertainties about the brewing wars in Europe and Asia. ${ }^{1}$

G. P. Mathy, American University, 4400 Massachusetts Avenue NW, Washington, DC 200I6, USA; email: mathy@american.edu. I'd like to thank Nicolas L. Ziebarth, seminar participants at the University of Iowa, Rui Esteves and two anonymous referees for helpful comments. All errors remain mine alone.

${ }^{1}$ Cogley and Sargent (2008) show that the Great Depression is a watershed for equity markets, with the Sharpe ratio, a market price of risk, being permanently higher after the Depression. 
Table I. Daily percentage increases or decreases in Dow Index, 1896-2013

\begin{tabular}{|c|c|c|c|c|c|}
\hline \multicolumn{3}{|c|}{ Increases } & \multicolumn{3}{|c|}{ Decreases } \\
\hline Rank & Date & $\%$ change & Rank & Date & $\%$ change \\
\hline I & $15 / 3 / 1933$ & $+I 5 \cdot 34$ & I & I9/Io/I987 & $-22.6 \mathrm{I}$ \\
\hline 2 & 6/Io/I93I & $+\mathbf{I} 4.87$ & 2 & 28/I0/I929 & -12.82 \\
\hline 3 & 3I/IO/I929 & +12.34 & 3 & 29/I0/I929 & - II.73 \\
\hline 4 & $21 / 9 / 1932$ & + II.36 & 4 & 6/II/I929 & -9.92 \\
\hline 5 & I3/IO/2008 & + I I.o8 & 5 & I 8/I2/I 899 & -8.72 \\
\hline 6 & 28/IO/2008 & + $\mathrm{I} 0.88$ & 6 & $12 / 8 / 1932$ & -8.40 \\
\hline 7 & $2 \mathrm{I} / \mathrm{IO} / \mathrm{I} 987$ & + IO.I5 & 7 & $\mathrm{I} 4 / 3 / \mathrm{I} 907$ & -8.29 \\
\hline 8 & 3/8/I932 & +9.52 & 8 & 26/I0/I987 & -8.04 \\
\hline 9 & II/2/I932 & +9.47 & 9 & $15 / 10 / 2008$ & -7.87 \\
\hline IO & I4/II/I929 & +9.36 & Io & $21 / 7 / 1933$ & -7.84 \\
\hline
\end{tabular}

Notes: Daily percentage return is daily change in log price of Dow Jones Industrial Average. Dates in bold indicate occurrence during I929-33 NBER recession.

I outline major events that could plausibly have driven uncertainty by examining the historical record, providing one answer to the question: what was a more fundamental cause for these uncertainty shocks? As stock prices are based on expectations of future profitability, increased uncertainty about future profitably should generate large gyrations in equity returns. I tie these events to stock return volatility and large 'jumps' in daily returns, which were contemporaneous with many uncertainty shocks that were buffeting the American economy.

The I930s in the United States saw volatility in equity returns which were unprecedented in both magnitude and persistence, as shown by Officer (1973) and Schwert (1989). This volatility did not result from steady negative returns, but instead the I930s saw some of the largest positive and as well as negative returns in US history, which can be clearly seen in Table I. The historical time series of stock volatility for the Dow Jones Industrial Average (DJIA) can be seen in Figure I. Figure 2 displays return volatility over the entire I929-4I period, where we can see that the period of most rapid decline in output and prices was also a period when stock volatility was high, while periods when output was rising are also times when stock volatility was low or falling.

I define an uncertainty shock as an increase in the dispersion (second moment) of expected future outcomes. In a Knightian framework (Knight 20I2) uncertainty shocks, as defined here, would be closer in spirit to the concept of Knightian risk where probabilities are known but outcomes become more dispersed. There is also the concept of Knightian uncertainty where probabilities cannot be assigned to future outcomes, such as in Ilut and Schneider (2014), which is based on ambiguity aversion as in the famous Ellsberg Paradox (Ellsberg 1961). This class of models is less tractable, though obviously very relevant to real-world discussions of uncertainty. 


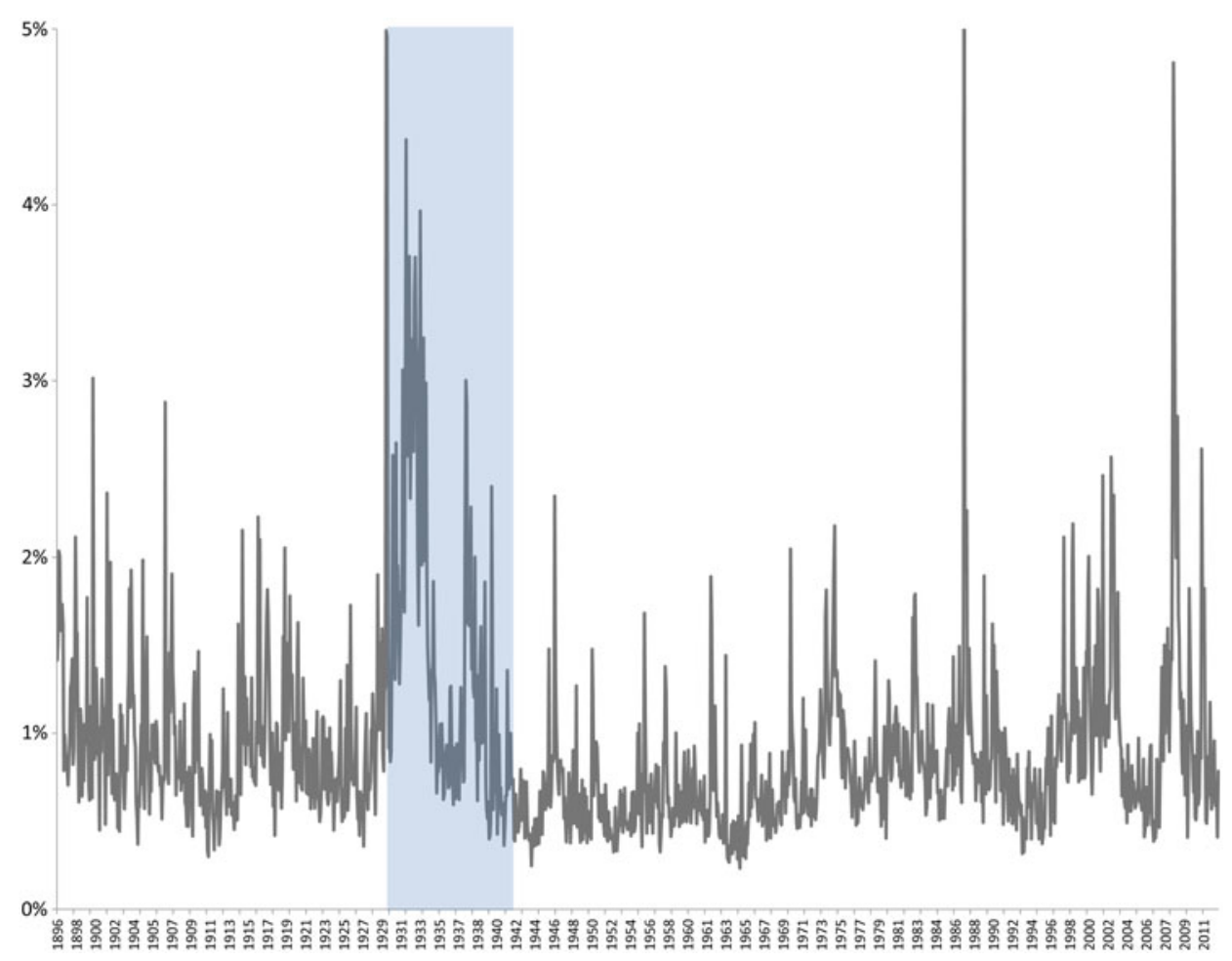

Figure I. Stock volatility, 1896-2012

Notes: Stock volatility is calculated as the monthly standard deviation of the Dow Jones Industrial Average stock returns (percentage). Stock returns are calculated as the daily change in the log of the Dow Jones Industrial Average. The shaded region is the 1929-4I Great Depression period.

In a financial context, uncertainty shocks express themselves either as uncertainty over future profitability or as uncertainty over the determinants of future discount rates, both of which will appear as increase return volatility. Dixit and Pindyck and their coauthors have produced an extensive literature on investment under uncertainty. ${ }^{2}$ In general in these models, firms face uncertainty over revenue and costs when making an irreversible investment. As some future states of the world can be characterized by low profits, firms delay investment (McDonald and Siegel I986). I follow Schwert's characterization of stock market volatility as directly reflecting economic uncertainty: ' $[\mathrm{T}]$ he volatility of stock returns reflects uncertainty about future cash flows and discount rates, or uncertainty about the process generating future cash

${ }^{2}$ See Pindyck (I99I, I993); Abel et al. (I996); Caballero and Pindyck (1996); Pindyck (I988); Majd and Pindyck (1987); Dixit and Goldman (I970); Dixit (1992, I993); Dixit and Pindyck (1994). 


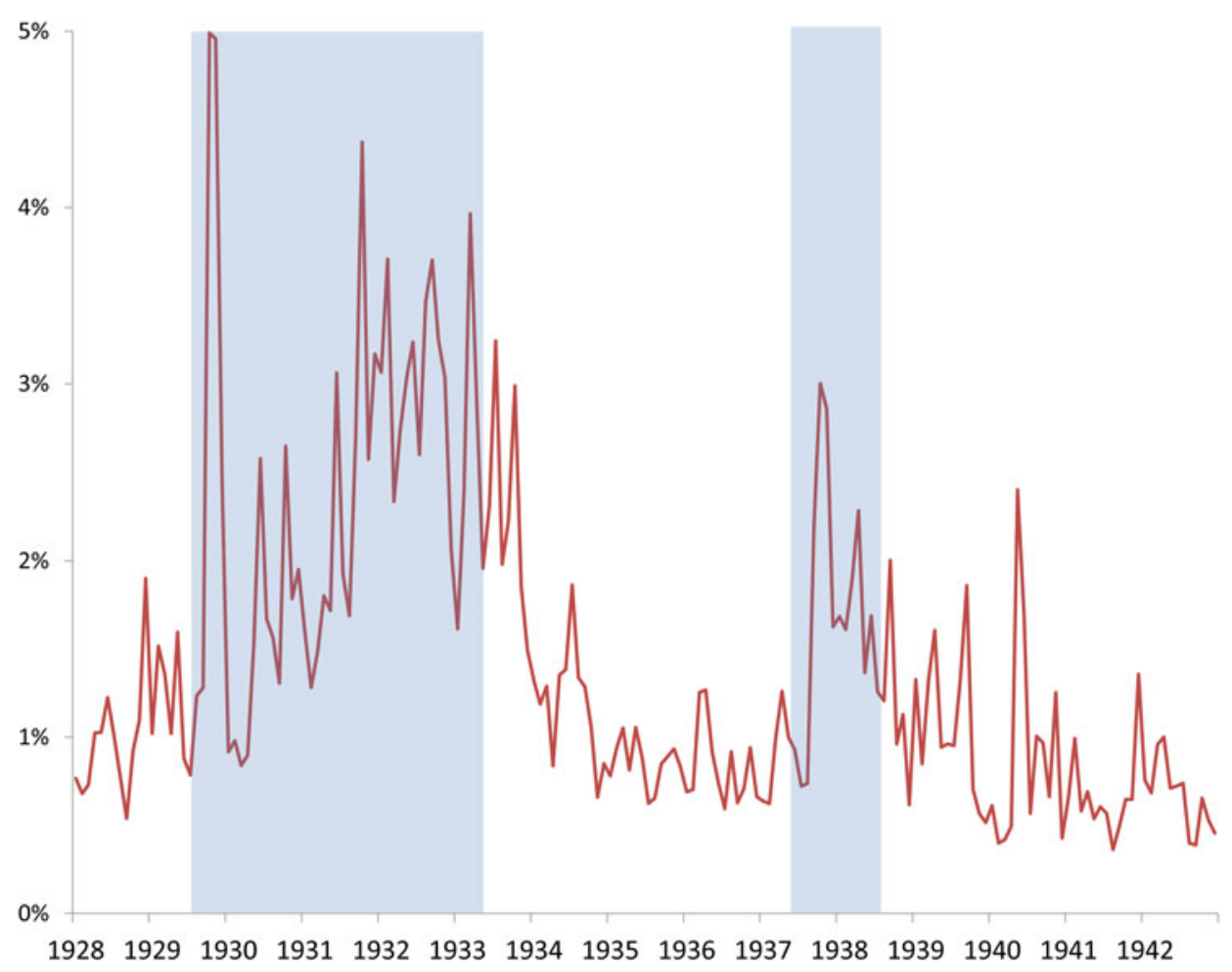

Figure 2. Stock volatility, 1928-42

Notes: Stock volatility is calculated as the monthly standard deviation of the Dow Jones Industrial Average stock returns (percentage). Stock returns are calculated as the daily change in the $\log$ of the Dow Index. NBER recession periods appear as shaded rectangles.

flows and discount rates' (Schwert I989, p. 85). But it is not simply the case that this volatility is driven by a smooth process of regular increases or decreases in returns. New information or 'news' about uncertainty arrives periodically, and this drives discontinuous jumps in stock returns that can be observed during a period of uncertainty, such as the I930s. ${ }^{3}$

Veronesi (I999) develops a financial model with a regime shift between high and low economic uncertainty which produces significant variation in stock volatility over time. This model provides a theoretical justification for the stylized fact of a high correlation between uncertainty and stock volatility. Following the intuition in Veronesi (I999), I argue that uncertainty shocks will correspond to periods of high volatility, as uncertainty over the expected profitability of firms generates high

3 See the voluminous financial literature about news and stock returns, e.g. Maheu and McCurdy (2004), which used methods similar to those used in this article. 
stock volatility. ${ }^{4}$ Volatility in discount rates would also generate higher stock volatility, as asset prices are determined jointly by discount rates and expected returns. This theory is both able to explain why stock returns made large upwards and downward movements as well as explaining the persistently high volatility through uncertainty, as this is a prediction of uncertainty theory. This argument can also help to explain why the American economy was in recession during these periods, as these uncertainty shocks would have reduced investment and consumption, which fell sharply during the Depression. To confirm the correct identification of uncertainty shocks from the historical record, I use the bipower variation test of Barndorff-Nielsen and Shephard (2006) to show that not only was stock volatility high, but also the level of stock returns was constantly gyrating in large upward and downward jumps at the same time. There are some periods with low uncertainty and high volatility, such as the late I990s, which see both high stock volatility and low jumps, as compared to the I930s which sees high volatility and many discontinuous jumps. I then analyze the historical record to show the types of events that could have given rise to high uncertainty during the periods when output was falling in the I93os.

An implication of the theory of investment under uncertainty, as in Dixit and Pindyck (I994), is that periods of high uncertainty should cause firms to postpone investment and consumers to postpone consumer durable purchases. As Bernanke (I983) argued, if enough consumers and firms postpone these expenditures, then aggregate expenditures would fall and a recession would result. Both measures of volatility are high during the I929-33 and I937-8 recessions, which makes it plausible that uncertainty shocks played a role in these declines. This article examines the historical record of this period to outline a series of events that are candidates for uncertainty shocks, and then matches these events to change in stock returns and stock volatility, as predicted by the theory of investment under uncertainty.

The rest of the article proceeds as follows. Section II outlines the test for stock return jumps using bipower variation. Section III outlines events in the I930s that could have driven these large increases in volatility and large increases in extreme jumps in stock returns. Section IV concludes.

While a Gaussian distribution roughly matches the distribution of stock returns in the data, the distribution of stock returns for the Dow Jones Industrial Average for I896-20I3 deviates significantly from a normal distribution. There remain 'fat tails', where the frequency of very large negative downward changes (and to some extent upward changes) in stock returns are larger than would be predicted with a normal distribution. To better model the distribution of stock returns, I will include a series of discontinuous 'jumps' which will arrive at a Poisson rate. This

${ }^{4}$ It is likely that an uncertainty shock is more 'shocking' during a period of high volatility than a period of low volatility, though the model considered in this article does not account for this phenomenon. 
jump-diffusion model of stock returns has a long history in the literature, beginning with Merton (I976) and continuing with models like that of Kou (2002). The I930s, especially during the I929-33 Great Collapse period, saw many of the largest declines in the Dow Jones Industrial Average, but this period also saw some of the largest gains in Dow history as well. These results are plotted in Table I, which shows clearly that this period saw both large downward and upward swings in the stock market. While assuming a Gaussian distribution is convenient, one can understand both the behavior of stock returns as well as how new information about uncertainty affects financial markets by examining discontinuous jumps, which are an important determinant of overall return volatility.

To separately identify jumps in the data from large observations of the diffusion part of the data-generating process, I use the bipower variation test of Barndorff-Nielsen and Shephard (2006), which identifies jumps in a jump-diffusion time-series. There are many alternative methods of testing for jumps, but I chose this method as it is prominent in the literature and also because of the limited number of high-frequency (daily) series available for this period. If other high-frequency data were available, the preferable method of cojumping of Dungey and Martin (2007), Dungey et al. (2009), Dungey and Hvozdyk (2OI2), Dungey and Gajurel (20I4), Claus and Dungey (20I6) would be a superior way to test for jumps. While there are other jump tests, such as Lee and Mykland (2008), Mancini and Renò (20 I I), Andersen et al. (20I2), I chose the BNS test due to its frequent use among financial practitioners, as well as the straightforward and transparent way the statistics are calculated.

These jump-diffusion processes combine the standard Brownian diffusion process with a jump process as follows:

$$
\frac{d Y_{t}}{Y_{t}}=\eta d t+\sigma_{t} d W+x d Z
$$

In this continuous-time framework $\mathrm{Y}$ is the stock index level, $\eta$ is the trend as a percentage, $\sigma$ is the standard deviation of changes, $\mathrm{x}$ is the average size of discrete jumps, $\mathrm{dW}$ is a standard Brownian motion process which follows a Gaussian distribution, and $\mathrm{dZ}$ follows a Poisson distribution and has a value of either o or I.

$$
[Y]_{t}=\operatorname{plim} \sum_{j=0}^{n-\mathrm{I}}\left(Y_{t, j+\mathrm{I}}-Y_{t, j}\right)^{2}
$$

and it is easy to show that $[Y]_{t}=\left[Y^{c}\right]_{t}+\left[Y^{d}\right]_{t}$, with $\left[Y^{d}\right]_{t}=\sum_{0 \leq g \leq t} \Delta Y_{u}^{2}$, and with $\Delta Y_{t}$ representing the jumps in Y. The null hypothesis of no jumps is formed by setting $[\mathrm{Y}]=\left[\mathrm{Y}^{c}\right]$. While there is a limiting case of continuous time, my dataset uses daily data so I will perform the test with daily returns, defined as $y_{t}=Y_{t}-Y_{t-\mathrm{I}}$. For daily 
returns, the bipower variation $[\mathrm{I}, \mathrm{I}]$ of a time-series over time $\mathrm{t}$ is defined as follows:

$$
Y_{t}^{[\mathrm{I}, \mathrm{I}]}=\sum_{j=2}^{t}\left|\gamma_{j-\mathrm{I}}\right|\left|\gamma_{j}\right|
$$

Barndorff-Nielsen and Shephard (2004) show that the above expression can be consistently estimated with

$$
[Y]_{t}-\left(\mu^{-2}\right) Y_{t}^{[\mathrm{I}, \mathrm{I}]}
$$

where $\mu=\sqrt{\frac{2}{\pi}}$. The above expression is simply the difference between the bipower variation and the quadratic variation, and will provide the basis for the BNS difference test.

To test for the presence of jumps in a time series, an estimator of integrated quarticity $\int_{0}^{t} \sigma_{u}^{4} d u$ is required. BNS propose quadpower variation, which is defined as follows:

$$
Y_{t}^{[\mathrm{I}, \mathrm{I}, \mathrm{I}, \mathrm{I}]}=\sum_{j=4}^{t}\left|\gamma_{j-3}\right|\left|\gamma_{j-2}\right|\left|\gamma_{j-\mathrm{I}}\right|\left|\gamma_{j}\right|
$$

The BNS difference test statistic has the following asymptotic distribution for daily returns. ${ }^{5}$

$$
\hat{D}=\frac{\left(\mu^{-2}\{Y\}_{t}^{[\mathrm{I}, \mathrm{I}]}-[Y]_{t}\right)}{\sqrt{\theta \mu^{-4}\{Y\}_{t}^{[\mathrm{I}, \mathrm{I}, \mathrm{I}, \mathrm{I}]}}} \rightarrow^{L} N(\mathrm{O}, \mathrm{I})
$$

There is also a ratio test that measures the ratio of quadratic variation to bipower variation.

$$
\frac{\{Y\}_{t}^{[\mathrm{I}, \mathrm{I}]}}{\sqrt{\theta\{Y\}_{t}^{[\mathrm{I}, \mathrm{I}]}}}\left(\frac{\mu^{-2}\{Y\}_{t}^{[\mathrm{I}, \mathrm{I}]}}{[Y]_{t}}-\mathrm{I}\right) \rightarrow^{L} N(\mathrm{O}, \mathrm{I})
$$

Intuitively, bipower variation is generated by the absolute value of the return multiplied by the lag, while the quadratic variation is the absolute value of the return multiplied by itself. Thus the difference between the two will capture how much the absolute value of the return changes between one day and the next. As the point estimate is related to the second moment, the relevant standard error is related to the square, and thus is a fourth-order moment, which is the quadpower variation. I use the BNS difference test to determine jumps, so the difference between quadratic and bipower variation is plotted for the entire period in

${ }^{5}$ Note that $\theta=\left(\pi^{2} / 4\right)+\pi-5$. 


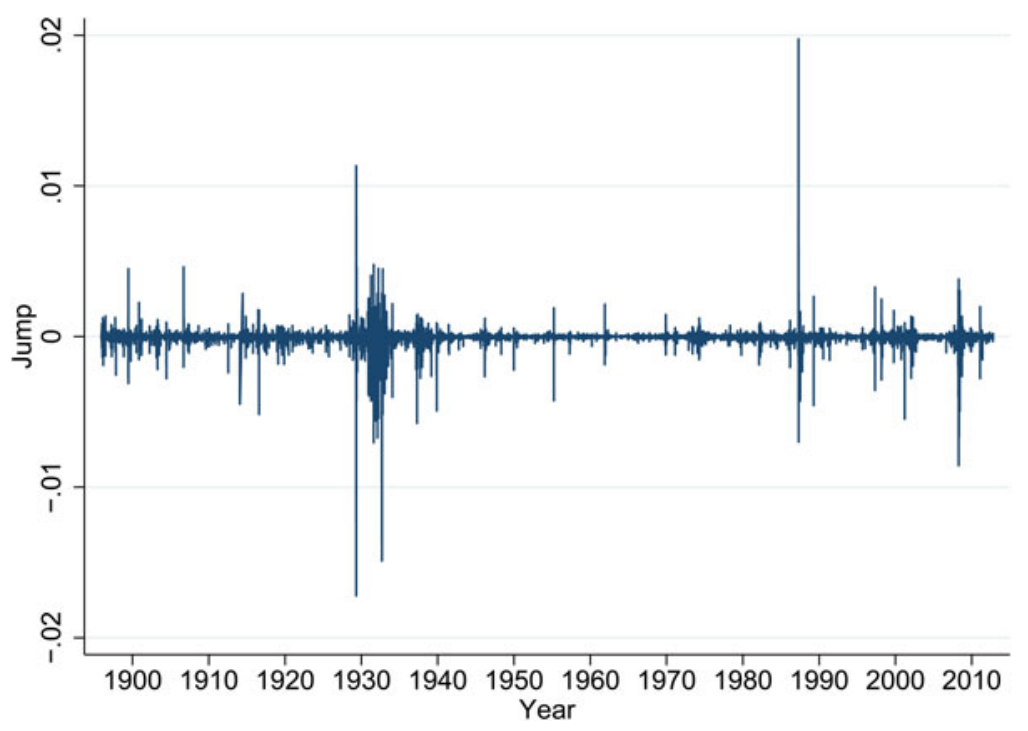

Figure 3. Jumps, 1896-2013

Notes: Jumps are the difference between the quadratic and bipower variation as outlined in Barndorff-Nielsen and Shephard (2006) applied to daily returns of the Dow Jones Industrial Average. Jump for 1987 crash is dropped to preserve appropriate scaling.

Figure 3, where the Depression period clearly appears as a period of significant and persistent jumps. Notice that this test statistic will appear as a large value for both upward and downward jumps, so both negative and positive jumps are evidence of jumps in the series. Table 2 shows the 20 largest jumps in Dow history, with those occurring in the recession period of I929-33 in bold. One can see that jumps predominate in this Great Contraction period with uncertain events corresponding to these jumps, which the reader will notice are both positive and negative. Other events that correspond to very large jumps are the I987 crash and the very uncertain period of October 2008, as well as the 1937 recession and some jumps related to the run-up to World War I.

I perform both the BNS difference test as well as the BNS ratio test using daily return data from the Dow Jones Industrial Average from I 896 to $2013 .{ }^{6}$ The tests yield very small p-values, so I can reject the null hypothesis of no jumps in the series for both the entire sample of I896-20I3 as well as the I929-4I Great Depression period. For the BNS difference test, I obtain a Z-value of -6.43 for the entire period, and -3.22 for the Great Depression, with both p-values significant at

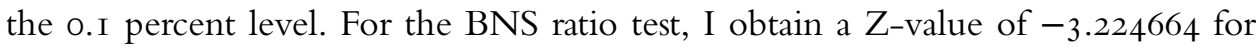
the entire sample and a Z-value of -2.8I7I48 for the Great Depression, with both

6 In the interest of conservatism, I have removed the observations from the closure of the NYSE during World War I and for the Oct. I987 Crash as outliers though these could easily be considered as jumps. 
Table 2. Twenty largest jumps as measured by BNS jump test statistic, 1896-2013

\begin{tabular}{|c|c|c|c|}
\hline Rank & Date & BNS jump & Reason \\
\hline I & I9/Io/I987 & 0.054 & I987 crash \\
\hline 2 & 28/10/I929 & 0.018 & I929 crash \\
\hline 3 & $15 / 3 / 1933$ & 0.017 & Emergency Banking Act \\
\hline 4 & 6/I0/I93I & 0.009 & Hoover Bank Plan \\
\hline 5 & $\mathrm{I} 3 / \mathrm{IO} / 2008$ & 0.009 & Bank bailout \\
\hline 6 & $28 / \mathrm{IO} / 2008$ & 0.008 & Monetary stimulus announced \\
\hline 7 & $21 / 9 / 1932$ & 0.008 & RFC to aid farmers \\
\hline 8 & II $/ 2 / 1932$ & 0.007 & Treasury Secretary Mellon resigns \\
\hline 9 & $\mathrm{I2} / 8 / \mathrm{I} 932$ & 0.007 & $\begin{array}{l}\text { Hoover accepts Republican presidential } \\
\text { nomination }\end{array}$ \\
\hline IO & 26/Io/I987 & 0.007 & I987 post-crash \\
\hline II & $6 / 5 / 1932$ & 0.006 & Major insurance merger \\
\hline $\mathrm{I} 2$ & I $5 / \mathrm{IO} / 2008$ & 0.006 & $\begin{array}{l}\text { Gov't buys bank shares/surprise negative } \\
\text { economic reports }\end{array}$ \\
\hline I 3 & I8/Io/I937 & 0.006 & Surprise negative economic reports \\
\hline $\mathbf{I} 4$ & I9/04/I933 & 0.006 & USA leaves gold standard \\
\hline 15 & $10 / 06 / 1932$ & 0.006 & $\begin{array}{l}\text { Congressman McFadden speech blasts Fed } \\
\text { for Depression }\end{array}$ \\
\hline I6 & OI/I $2 / 2008$ & 0.005 & NBER declares recession \\
\hline I7 & I7/09/2008 & 0.005 & Post-9/I I jitters \\
\hline I 8 & I7/09/2008 & 0.005 & AIG bailout \\
\hline 19 & $05 / 10 / 1932$ & 0.005 & $\begin{array}{l}\text { Farmer road blockade / Protest over low } \\
\text { food prices }\end{array}$ \\
\hline 20 & OI/O2/I9I7 & 0.005 & Germany resumes unrestricted submarine warfare \\
\hline
\end{tabular}

Notes: Dates in bold indicate occurrence during I929-33 NBER recession. Events derived from New York Times and Commercial and Financial Chronicle. BNS test statistic outlined in Barndorff-Nielsen and Shephard (2006).

tests recommending rejection at a I percent level. Thus the BNS tests clearly point to the existence of jumps. Bloom (2009) also performs the BNS difference and ratio tests, and finds support for jumps in return for the postwar as I do for the interwar period.

I also display in Figure 4 the percentage of the month that features 'high jumps', which I define to be in the 95th percentile of jumps over the entire period. A comparison to the policy uncertainty index of Baker et al. (2015), based on newspaper mentions of policy uncertainty, is featured in Figure 5, scaled to be comparable. While the economic policy uncertainty index is higher during the New Deal period of 1934-4I before the war, the jump series is higher during the recessionary periods of I929-33 and I937-8, perhaps reflecting the prominent discussion of uncertainty in the newspaper on which the policy uncertainty index is based, relative to the actual impact of financial markets in the jumps measure. It is plain to see that the 


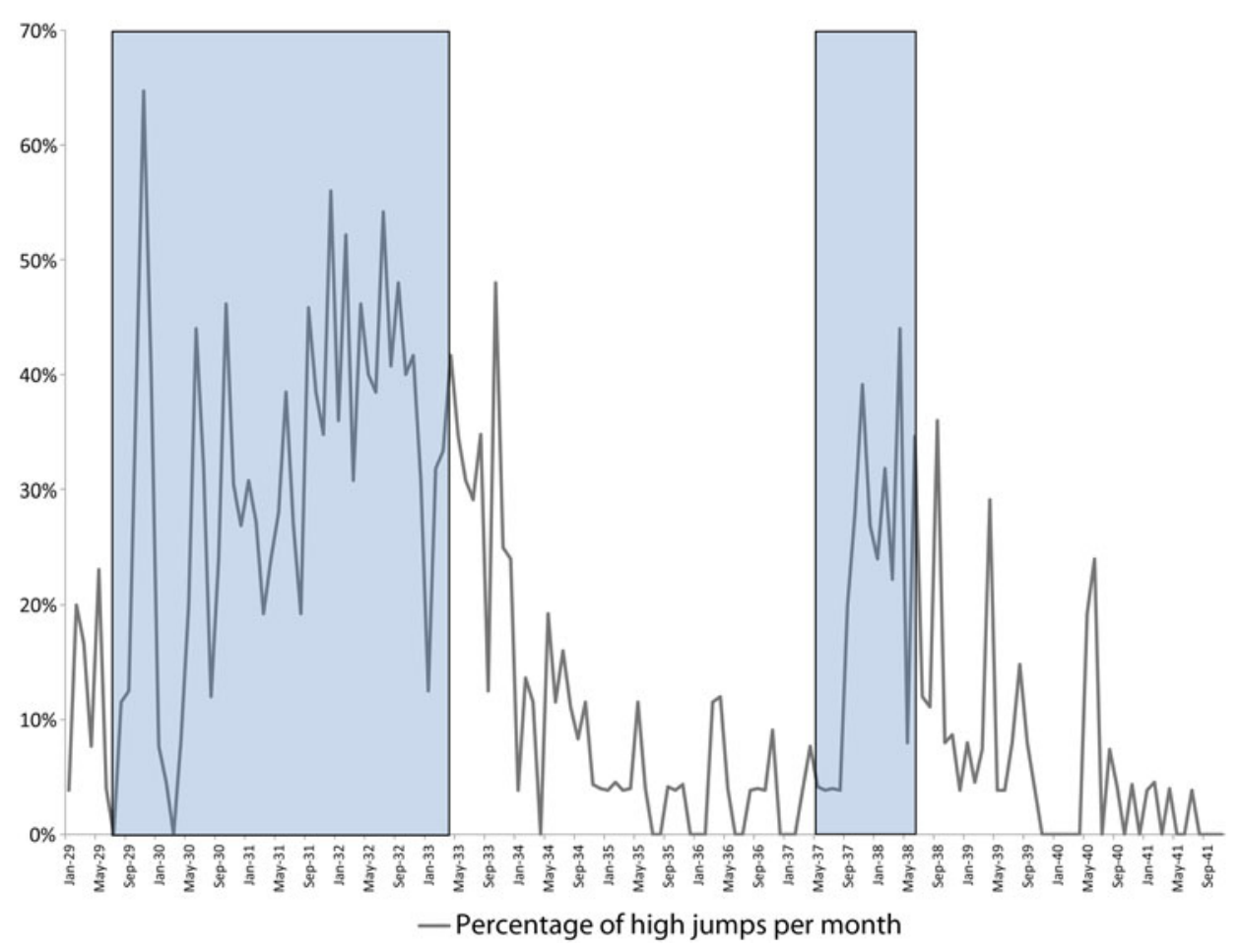

Figure 4. Jump percentage, 1929-38

Notes: Percentage of high jumps per month is the percentage of days in a month with a jump in the largest 5 percent of jumps over the entire sample, I 896-20I3. Jumps are the difference between the quadratic and bipower variation, as outlined in Barndorff-Nielsen and Shephard (2006), applied to daily returns of the Dow Jones Industrial Average. The two NBER recession periods of I929-33 and I937-8 are displayed as the shaded regions.

period with many jumps is also the period when stock volatility is high, which is consistent with the uncertainty hypothesis where stock prices should exhibit large returns jumps and high stock volatility during uncertainty periods. Recession periods are also indicated, which are contemporaneous with the periods of high jumps, which is consistent with uncertainty shocks generating both discontinuous jumps and these sharp recessions.

\section{III}

Bloom (2009) points to major uncertainty shock events in the postwar era which coincided with major stock volatility and significant uncertainty such as the Cuban missile crisis, the assassination of John F. Kennedy, the Gulf War, the Asian financial crisis, 9/I I and the 2008 financial crisis. In a related paper, Charles and Darné (20 I 4) identify 


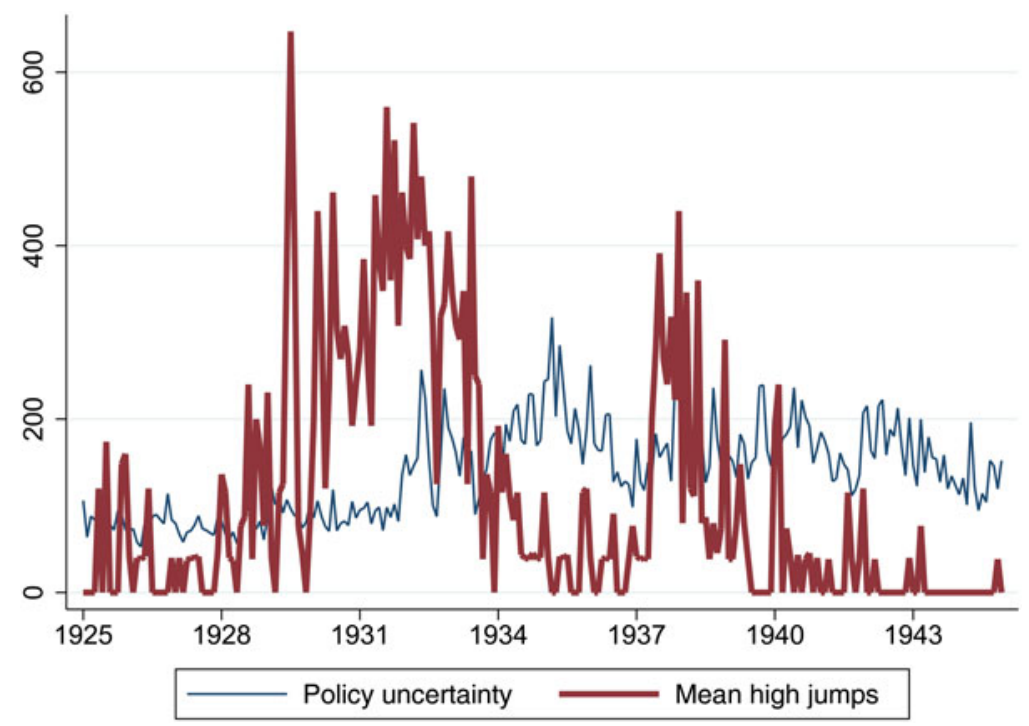

Figure 5. Comparison of economic policy uncertainty index and large jumps

Notes: Economic policy uncertainty index from Baker et al. (2015) and based on counts of newspaper articles per month containing terms related to economy/uncertainty and policy terms. 'Mean high jumps' is average number of large jumps per month from I925 to I944. A large jump is defined as one of the largest 5 percent of jumps in whole sample from I 896 to 2013 .

large shocks in the volatility of the Dow Jones Industrial Average from I928 to 2013 and, similarly, find that both the I929-34 and I937-8 periods see elevated return volatility. Moreover, these authors use a similar narrative approach to match large jumps to particular events, though they do not make the explicit connection to uncertainty and do not analyze some lower-frequency increases in uncertainty such as banking failures and the possibility of an end to the capitalist system.

Using historical print sources, primarily books and articles from publications like the Commercial and Financial Chronicle and the New York Times, I construct a timeline of Depression uncertainty shock events in the same vein as these authors, which can be seen in Figures 6 and 7. All the events are listed in Table 3 with a corresponding classification of the uncertainty shock type, which matches these events to large jumps and stock volatility during the I929-4I Great Depression. Naturally this narrative is somewhat subjective and other interpretations of the historical record are possible, but I have done my best to present an unbiased timeline that helps explain the behavior of asset prices during this period through the lens of the theory of uncertainty shocks.

The roots of the crisis of 1929 can be found in the economic and asset boom that preceded the crash. In order to combat stock market speculation and a stock market bubble, the Federal Reserve raised discount rates to discourage stock buying using 


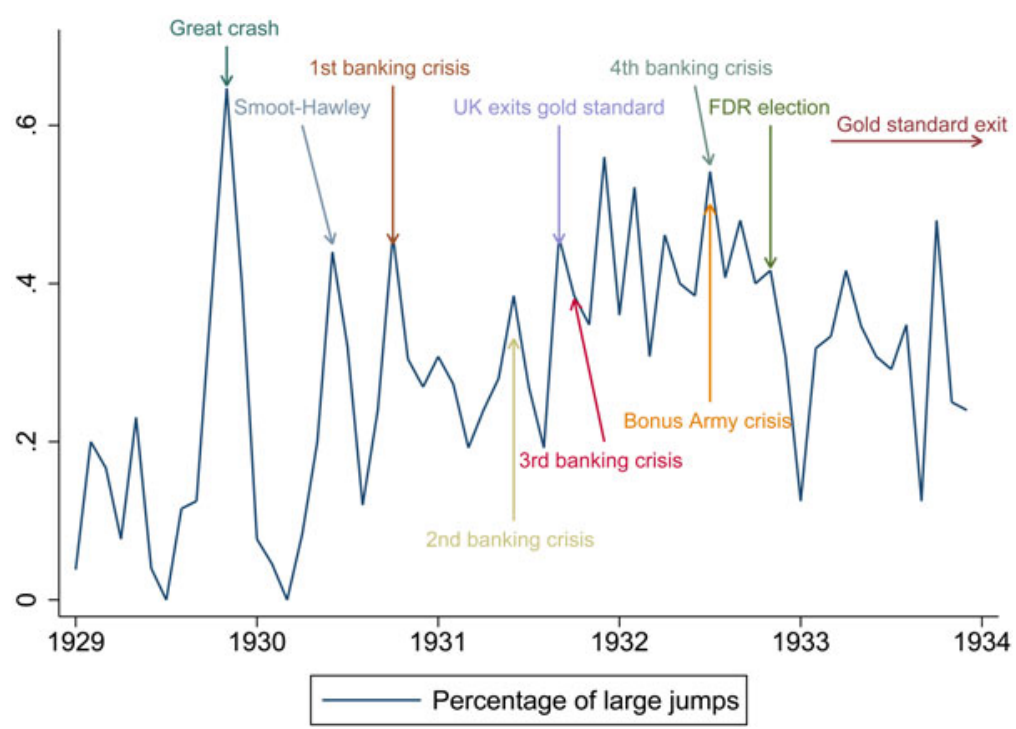

Figure 6. Large jump events, 1929-33. Large jumps are the largest 5 percent of jumps in the sample as calculated by BNS difference test (Barndorff-Nielsen and Shephard 2006). Percentage of large jumps is the ratio of number of days with large jumps to total days in month.

margin borrowing and to prevent the economy from overheating (Eichengreen I996). While this action slowed output growth, its effect were debated for a long period at the Fed and the discount rates were relatively well communicated relative to other monetary policy at the interwar Fed. The United States eventually did experience a mild downturn, as the peak of industrial production and the official start of the recession can be dated to the summer of $1929 .^{7} \mathrm{Up}$ to this point, I see no role for uncertainty as an explanatory factor in the nascent disaster. Monetary tightening, as outlined in Hamilton (I987), is sufficient to explain the mild decline in economic activity.

Most likely due to the unsustainable rise of securities prices between I928 and I929, stocks crashed in October I929 in one of the largest financial routs in American history. In the wake of this stock crash, the character of the downturn changed significantly. However, while the recession may have appeared to be mild to observers at the time, the Great Crash of I 929 would fundamentally change the nature of the downturn, as Friedman and Schwartz argue:

During the two months from August 1929 to the crash, production, wholesale prices, and personal income fell at annual rates of 20 percent, 7.5 percent, and 5 percent, by October respectively. In the next twelve months, all three series fell at appreciably higher rates: 27 percent, I 3.5 percent, and I7 percent, respectively. All told, by October I930, production had fallen 26

7 While the stock market crash looms large in popular accounts of the Depression, it is clear that the Great Crash occurred with a recession already well underway. 


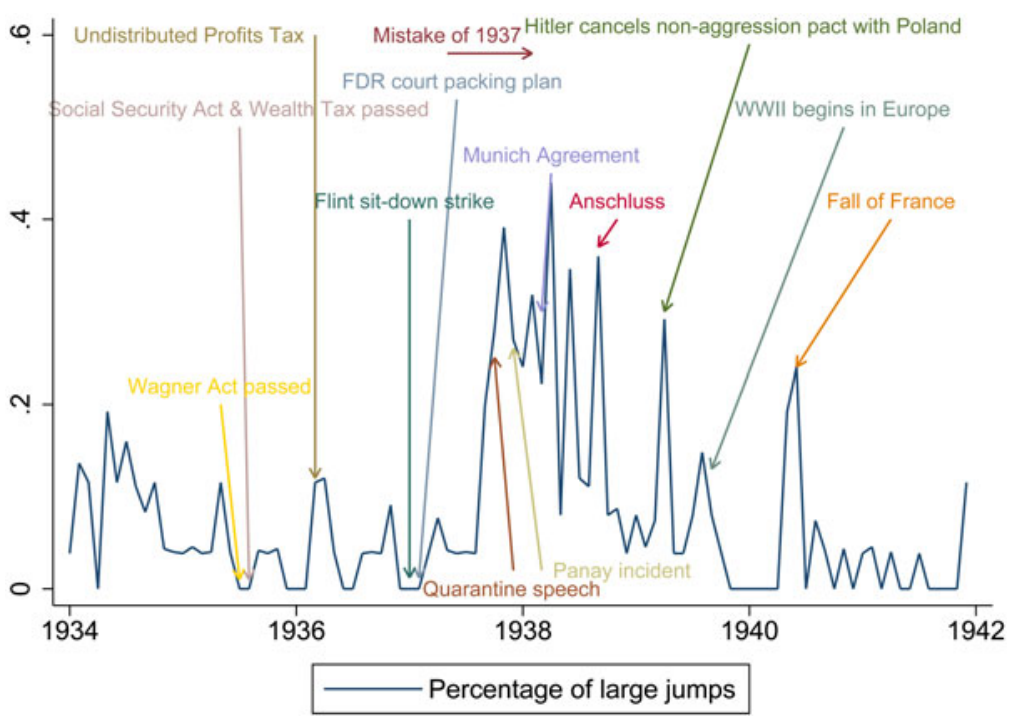

Figure 7. Large jump events, 1934-8. Large jumps are the largest 5 percent of jumps in the sample as calculated by BNS difference test (Barndorff-Nielsen and Shephard 2006). Percentage of large jumps is the ratio of number of days with large jumps to total days in month.

percent, prices, I4 percent, and personal income, I6 percent ... Even if the contraction had come to an end in late I930 or early I93 I, as it might have done in the absence of the monetary collapse that was to ensue, it would have ranked as one of the most severe contractions on record. (Friedman and Schwartz I97I, p. 306)

Friedman and Schwartz are well known for their monetarist explanation for the Great Depression. But one important, perhaps underappreciated, aspect of their argument is the central role that uncertainty plays in their monetary theory of the Depression. Friedman and Schwartz argue, as Romer (I990) does, that uncertainty was a direct result of the Great Crash of I929.

Partly, no doubt, the stock market crash was a symptom of the underlying forces making for a severe contraction in economic activity. But partly also, its occurrence must have helped to deepen the contraction. It changed the atmosphere within which businessmen and others were making their plans, and spread uncertainty where dazzling hopes of a new era had prevailed. It is commonly believed that it reduced the willingness of both consumers and business enterprises to spend, ... (Friedman and Schwartz I97I, p. 306)

Romer (I990) examined contemporary business forecasts, which became markedly more uncertain after the crash. While monetary factors were most likely another trigger for the price collapse, the Great Crash generated a sense of uncertainty among businesses and consumers. After October I929 stock volatility and return jumps fell significantly, such that these uncertainty measures are low by early I930. However, the largest declines in the DJIA in US history occur on 28 and 29 
Table 3. Uncertainty shock events

\begin{tabular}{|c|c|c|}
\hline Uncertainty shock & Date & Type of uncertainty \\
\hline Great Crash & Oct 1929 & Stock market crash \\
\hline Smoot-Hawley & Jun I930 & Large tariff increase \\
\hline First banking crisis & Nov-Dec I930 & Banking crisis \\
\hline Second banking crisis & Apr-Aug I93 I & Banking crisis \\
\hline UK gold standard exit & Sep I93 I & Gold standard uncertainty \\
\hline Third banking crisis & Sep-Oct I93 I & Banking crisis \\
\hline Fourth banking crisis & Jun-Jul I 932 & Banking crisis \\
\hline Bonus Army crisis & Jul I932 & Political uncertainty \\
\hline FDR election & Nov 1932 & Policy uncertainty \\
\hline First hundred days & Mar-Jun I933 & Policy uncertainty \\
\hline US gold standard exit & Mar I933 - Jan I934 & Gold standard uncertainty \\
\hline National Recovery Agency & Jun I933 & Policy uncertainty \\
\hline 'Mistake of I937' & May $1937-$ Feb I938 & Monetary policy uncertainty \\
\hline Quarantine speech & Oct 1937 & War uncertainty \\
\hline Panay incident & Dec I937 & War uncertainty \\
\hline Munich Agreement & Mar I938 & War uncertainty \\
\hline Anschluss & Sep 1938 & War uncertainty \\
\hline $\begin{array}{l}\text { Hitler cancels non-aggression } \\
\text { pact with Poland }\end{array}$ & Apr I939 & War uncertainty \\
\hline WWII begins in Europe & Sep I939 & War uncertainty \\
\hline Fall of France & Jun I940 & War uncertainty \\
\hline Non-uncertainty shock & Date & Type of uncertainty \\
\hline Wagner Act & Jul I935 & Policy uncertainty \\
\hline Social Security Act & Aug 1935 & Policy uncertainty \\
\hline Wealth Tax & Aug I935 & Policy uncertainty \\
\hline Undistributed Profits Tax & Mar 1936 & Policy uncertainty \\
\hline Flint sit-down strike & Dec I936 - Feb I937 & Policy uncertainty \\
\hline FDR court packing plan & Feb-Jul I937 & Policy uncertainty \\
\hline
\end{tabular}

Notes: See text for discussion of uncertainty events and Figures 6 and 7 for associated stock volatility. Non-uncertainty shocks identified by low volatility and uncertainty shock events by high volatility.

October and 6 November, with declines of I 2.82, I I.73 and 9.92 percent respectively. ${ }^{8}$ Contrary to the popular misconception that the Great Crash was a single day's decline, October 1929 actually saw several days of extreme jumps. Moreover, the third largest increase in Dow Jones history occurred on 3 I October when some investors purchased stocks in a wave of optimism.

${ }^{8}$ See Table I. The jump of 28 October appears as the second highest according to the BNS test statistic, after the 1987 crash. 
Several events that generated euphoria and disappointment are evident from both Table I, which lists the largest daily returns, and Table 2, which lists the largest jumps in Dow history. ${ }^{9}$ On I 4 November I929, a discount rate cut by the New York Federal Reserve from 5 to 4.5 percent sparked optimism that the crash of the month before would not last (Friedman and Schwartz I97I, p. 367) and led to a Io percent increase in the Dow. On 6 October I93 I, the Dow Jones surged higher by over I 2 percent, the fifth highest jump in US history, despite coming in the wake of the UK departure from the gold standard and another wave of banking failures. On that date, President Hoover outlined a plan for a banking coalition to improve confidence in the banking system, which led to optimistic buying (Hoover I93 I).

On I I February I932, the resignation of Hoover's liquidationist Treasury Secretary, Andrew Mellon, generated a wave of optimism that the economy would improve as a result of his resignation, which caused a large jump in stocks and the ninth largest jump in US history. ${ }^{10}$ On 3 August 1932, the Dow rose almost ro percent on the news that General Motors would pay a dividend again after a long suspension, which pointed some towards expectations of recovery. On I2 August I932, the DJIA fell by over 8 percent after Herbert Hoover accepted to be the Republican nominee in I932, with the prospect that his ineffective policies would continue.

On Io June 1932 Congressman Louis McFadden gave a speech that blamed the Federal Reserve and Wall Street for the Depression, which raised the prospect of increased regulation and scrutiny of the financial system. On 2I September I932, the Dow rose by over I I percent, the eighth largest jump, on the news that the Reconstruction Trust Finance Corporation, a government agency meant to support the banking system, would support agriculture as well. The largest daily return (an increase of I5.34 percent) occurred on Is March I933 when the Emergency Banking Act and the bank holiday ended. As these programs were concluded successfully, only solvent banks remained. This decisively ended the banking panics of the early I930s and investors could expect a much more profitable future (Friedman and Schwartz I97I). ${ }^{11}$

Wicker (200I) identifies four major periods of banking crises, which largely line up with the banking crises identified by Friedman and Schwartz (I97I). These banking crises took place from November to December I930, April to August I93 I,

9 These events are identified using newspaper accounts of the time or from Charles and Darnè (20I4). There was a general sense of uncertainty, especially in I93 I, related to banking failures, particularly in Europe, as discussed in the 'National City Bank of New York', Commercial and Financial Chronicle, 26 Sept. I93 I.

10 Mellon famously stated that his preferred policy response to the Great Depression was to 'liquidate labor, liquidate stocks, liquidate farmers, liquidate real estate... it will purge the rottenness out of the system. High costs of living and high living will come down. People will work harder, live a more moral life. Values will be adjusted, and enterprising people will pick up from less competent people' (Hoover I952).

11 This appears as the third highest jump in the BNS difference series, behind the Great Crash. 
September to October I93 I and June to July I932. ${ }^{12}$ It is intuitive that large-scale bank failures would reduce confidence about the future. Bank runs and uncertainty about whether one's life savings would be safe could only have added to the existing uncertainty. Friedman and Schwartz argued that the increase in uncertainty in the I93os could explain the decline in monetary velocity. In this theory, economic agents would hold money due to a 'precautionary savings' effect, which is quite similar to a real-option effect due to uncertainty at the firm level.

Other things being the same, it is highly plausible that the fraction of their assets individuals and business enterprises wish to hold in the form of money, and also in the form of close substitutes for money, will be smaller when they look forward to a period of stable economic conditions than when they anticipate disturbed and uncertain conditions ... The more uncertain the future, the greater the value of such flexibility and hence the greater the demand for money is likely to be. (Friedman and Schwartz I97I, p. 673)

Thus we have another channel whereby uncertainty can reduce aggregate demand, through a monetary channel in this case. 'The contraction instilled instead an exaggerated fear of continued economic instability, of the danger of stagnation, of the possibility of recurrent unemployment. The result, from this point of view, was a sharp increase in the demand for money, accounting for the magnitude of the decline in velocity from I929 to I932' (Friedman and Schwartz I97I, p. 673). Cole and Ohanian (200I) find that the banking collapse was not a major factor in the decline of output from I929 to I933, as only 0.4 percent of banking deposits were lost from I930 to I932, which was similar ratio as for the I920-I recession. Also, Cole and Ohanian (200I) are not able to generate a significant decline in output as a result of banking failures from their general equilibrium model. However, while the direct effect of these banking failures may not be very large, the uncertainty effect of banking failures on household behavior could still be sizeable. For example, uncertainty over potential banking failures caused households to pull their money out of banks and reduced monetary velocity. Thus the FriedmanSchwartz monetary hypothesis can be seen through an uncertainty lens where the sharp decline in velocity is due, in large part, to these uncertainty shocks.

While tariffs did rise astronomically in the wake of the Smoot-Hawley Tariff, the direct impact was clearly too small to have been a primary explanation for the Great Depression (Eichengreen I988). However, this tariff could have a significant uncertainty effect, as argued by Archibald and Feldman (I998) and discussed in the Wall Street Journal. ${ }^{13}$ Indeed, there is a spike in stock volatility in June I930 when the Smoot-Hawley tariff was signed into law. Also, the extent of retaliation by American trading partners was uncertain: would other countries raise tariffs on American products? Canadian tariffs did rise significantly over this period in

12 A fifth crisis, from February to March I933, was viewed somewhat differently by Wicker, as there were no banking failures due to the bank holiday.

13 'See tariff end spur to trade', Wall Street Journal, i 8 March I937, p. I3. 
retaliation. Elsewhere nominal tariffs rose quickly, and volatile and unpredictable deflation made real tariff rates uncertain (Hamilton I992). While the Smoot-Hawley tariff was not a large uncertainty event on its own, it is plausible that this major policy change increased uncertainty. Indeed, the Dow Jones Industrial Average fell by 6 percent on I6 June when passage of the Smoot-Hawley Tariff was assured.

While in hindsight it is clear that the end of the gold standard was necessary for recovery (Eichengreen I996), during the Depression the 'gold standard mentality' was prevalent (Mouré 2002); countries would stay on the gold standard until the costs became too much to bear. This happened to the United Kingdom in September I93 I, and jumps increased during this month. It was unclear whether the British departure would drive the United States to leave the gold standard as well. As gold flowed to the UK the money supply in the United States fell and a financial and banking crisis resulted. In response, the Fed raised interest rates to preserve the gold standard, though of course this further worsened the negative effects of the financial crisis. Ferderer and Zalewski (1999) find that uncertainty propagated the Great Depression as doubts about a country's commitment of the gold standard lead to interest rate volatility, which then results in output declines; this channel can be seen in operation in September I93 I.

The Great Depression brought widespread hunger and unemployment, so it is perhaps unsurprising that support for radical policies grew. A Roman Catholic priest, James Cox, led 25,000 unemployed Pennsylvanians on a march on Washington in January 1932 to push for increased relief for the unemployed and stronger labor unions. This was a prelude for the much larger Bonus Army marches of the spring and summer. Veterans of World War I were promised, through I924 legislation, a Veteran's Bonus, to be paid in I945. Widespread unemployment and poverty among veterans during the I930s drove a push by veterans' groups for the bonus to be paid early, and some I7,000 veterans and their families went to Washington to lobby the government. Media reports claimed that the veterans' groups were largely composed of communists and criminals. General MacArthur saw the marchers as revolutionaries intent on overthrowing the Republic, a sentiment with which Patrick J. Hurley, the Secretary of War, enthusiastically agreed (Lisio I967).

While these sentiments may have been overblown, the perceived probability of violence and radicalism among well-trained veterans in the heart of the nation's capital could not but generate a sense of uncertainty. The eviction of the Bonus Army on 28 July coincides with a substantial increase in the percentage of large jumps. The eviction began with two marchers being killed by police. As the crisis intensified, MacArthur commanded a tank column, ordering a cavalry charge and infantry armed with bayonets and vomiting gas to disburse the veterans (Dickson and Allen 2006). ${ }^{14}$ On 5 October I932, the Minnehaha County Farmers' Holiday

14 The veterans would eventually receive their bonus in I936, when Congress passed the Bonus bill over President Roosevelt's veto. 
Association, a farmers' organization, blocked roads in Sioux Falls to protest low agricultural prices. Their blockade was part of a supply-side boycott of farmers refusing to sell their farm products until prices rose to protect agricultural surpluses. These Farm Holiday Associations threatened significant rural unrest, in keeping with the general instability of the time, and this event coincided with a major jump in the Dow Index.

Uncertainty resulting from the gold standard's future was discussed in the context of the British departure from gold in I93 I. Friedman and Schwartz also saw significant uncertainty in 1933 regarding the status of the gold standard in the United States under a Roosevelt administration:

The rumors about gold were only one part of the general uncertainty during the interregnum about future financial and economic policy. Under ordinary circumstances, it would have been doubtful that such rumors and such uncertainty would be a major force accounting for so dramatic and widespread a financial panic. But these were not ordinary circumstances. The uncertainty came after more than two years of banking difficulties in which one wave of bank failures had followed another and had left the banking system in a particularly vulnerable position. The Federal Reserve itself participated in the general atmosphere of panic. Once the panic started, it fed on itself. (Friedman and Schwartz I97I, p. 332)

Roosevelt did not initially have a clear position on the gold standard, so there was some uncertainty over his potential gold standard policies during the election. This uncertainty can be seen during his inauguration as president (March I933), at the time of Executive Order 6IO2, which forced the sale of private gold holdings to the government (April I933), and the Gold Reserve Act (January I934), which set gold's price at $\$ 35$ an ounce. ${ }^{15}$ The gold price floated between March 1933 and January I934, the period during which there are the largest jumps in returns; this could be due to lingering uncertainty over the gold standard prior to the repegging of the dollar at the rate of $\$ 35$ per troy ounce. The Gold Reserve Act also set up an Exchange Stabilization Fund, which purchased gold in exchange for freshly created money; this put in place a more clearly expansionary monetary policy (Wicker I97I).

For Friedman and Schwartz, monetary policy can work better if it is not impeded by the negative impacts of uncertainty. 'After three years of economic contraction, there must have been as many forces in the economy making for revival, and it is reasonable that they could more readily come to fruition in a favorable monetary setting than in the midst of continued financial uncertainty' (Friedman and Schwartz I97I, p. 324). While this study does not address the interaction between uncertainty and monetary policy effectiveness, Vavra (2013) and Bloom et al. (2007) found monetary policy was less effective during volatile or uncertain times, confirming Friedman and Schwartz's intuition. This lingering uncertainty at the beginning of the recovery can help explain why recovery was not more rapid given the sharp change in monetary policy from contractionary to expansionary. Other policies, like the National

15 The price of gold would remain $\$ 35$ an ounce until the end of the Bretton Woods system in the I970s. 
Industrial Recovery Act (NIRA), represented major departures from existing policy and significant interventions in the American economy of the time (Cole and Ohanian I999).

Support for existing political and economic frameworks receded during the I930s. With widespread hunger and unemployment, it is perhaps unsurprising that support for radical policies and actions rose. This rising tide of populism naturally made business uncertain about its future prospects. Merton (I985, p. I I 85 ) also argued that there was significant uncertainty about the survival of capitalism: 'With the benefit of hindsight, we know that the US and world economies came out of the Depression quite well. At the time, however, investors could not have had such confident expectations. ${ }^{16}$ Voth (2002) found that stock volatility and uncertainty rose during waves of strikes and other political uncertainty in Europe, where the threats of upheaval and violence were tragically realized. The Roosevelt administration was well aware of the threats of upheaval they faced. Franklin Delano Roosevelt (FDR) remarked to John Nance Garner, his vice-president, on the way to his inauguration: 'I had better be a good president or I will be the last one' (Cowley I98 I, p. I 52) Other observers shared these sentiments:

Before March 4th, America was in a state of extreme shock. No one would ever know, General Hugh S. Johnson later said, 'how close were we to collapse and revolution. We could have got a dictator a lot easier than Germany got Hitler.' 'I do not think it is too much to say,' wrote Tugwell, 'that on March 4 [Roosevelt's inauguration] we were confronted with a choice between an orderly revolution - a peaceful and rapid departure from past concepts - and a violent and disorderly overthrow of the whole capitalist structure.' (Schlesinger 2003 b, p. 22)

This was not idle speculation. General Smedley Butler, who had been active with the Bonus Army, would later be approached by a group of executives and conservatives opposed to Roosevelt. The plan of the 'Business Plot' was to have Butler lead a veterans' group in overthrowing Roosevelt and imposing a authoritarian government more favorable to opponents of the New Deal. While this plot was largely ridiculed at the time and even today, when Butler testified in I934 an official government investigation found these allegations to be true (Schlesinger 2003b). Farmers were also hard-hit by the Depression and this discontent could have easily become violent had the farm crisis not been resolved.

The seething violence in the farm belt over the winter - the grim mobs gathered to stop foreclosures, the pickets along the highways to prevent produce from being moved to town made it clear that patience was running out. In January I933, Edward A. O'Neal, the head of the Farm Bureau Federation, warned a Senate committee: 'Unless something is done for the American farmer we will have revolution in the countryside within less than twelve months.' (Schlesinger 2003 b, p. 28)

16 Cited in Voth (2002, p. 2). 
While it is difficult to point to specific events where the possibility of regime change was more salient, stock volatility and return jumps are high during the period I929-34 when this uncertainty was more salient, and after 1934 when recovery was taking hold and support for existing political and economic structures rose, uncertainty fell as well.

Criticism of Roosevelt was prevalent in the I930s, as the election of 1932 brought to power an executive and legislative branch that was highly supportive of an expanded role of government in the economy. This unprecedented government intervention in the economy was opposed by critics like the 'Old Right' as moves towards socialism or fascism (Hoover I952). Schumpeter argued that the major legislative changes caused uncertainty about the path and effects of government policy.

The subnormal recovery to I935, the subnormal prosperity to 1937 and the slump after that are easily accounted for by the difficulties incident to the adaptation to a new fiscal policy, new labor legislation and a general change in the attitude of government to private enterprise all of which can be distinguished from the working of the productive apparatus as such. So extensive and rapid a change of the social scene naturally affects productive performance for a time, and so much the most ardent New Dealer must and also can admit. I for one do not see how it would otherwise be possible to account for the fact that this country which had the best chance of recovering quickly was precisely the one to experience the most unsatisfactory recovery. (Schumpeter [1942] I994, pp. 64-5)

This 'regime uncertainty' argument has continued to influence modern scholars. Higgs (1997) argues that the uncertainty regarding private property rights during the Roosevelt administration explains the weak investment seen during the I93os. As policies were unclear, business did not want to invest given the uncertain future. This is similar to the 'wait-and-see' effect discussed earlier. Higgs lists some events that could have generated regime uncertainty, but this is simply a list of New Deal policies and does not identify more or less important policies. I will focus on major New Deal legislation that had significant implications for the economy, to see if these events acted as uncertainty shocks. ${ }^{17}$ Endogeneity may be a concern here as the economic downturn, partially driven by the uncertainty of I929-33, played a big role in the New Deal landslide of I932, and thus the downturn could have generated some uncertainty. However, Baker and Bloom (2013) show that natural disasters, clearly exogenous events, generate declines in output through the channel of uncertainty, addressing this endogeneity issue, though Bloom (2013) finds that uncertainty is, to some extent, endogeneous.

Roosevelt's first hundred days saw a unprecedented amount of legislation introduced by New Deal supporters who dominated both the executive and legislative branches. The Federal Emergency Relief Administration (FERA) expanded federal anti-poverty programs, the AAA greatly expanded federal intervention in agricultural

17 Cole and Ohanian (2004) also argue that the New Deal impeded recovery due to its suspension of antitrust laws and support for labor unions, which cartelized output and labor markets. They do not argue for an uncertainty argument specifically, though uncertainty stemming from the New Deal could also be detrimental to economic recovery in a similar fashion. 
markets to aid farmers, and the RFC started to purchase the banking shares of troubled banks, while Roosevelt's bank holiday shuttered all banks temporarily to try to weed out insolvent banks. All of these changes are often pointed to as a primary cause of elevated uncertainty during this period. In terms of generating a sense of uncertainty, the NIRA is perhaps the clearest candidate. This Act put in place the National Recovery Administration (NRA) in June I933. This allowed business to collude and set minimum standards for wages and prices. Thousands of pages of codes were printed to regulate almost all aspects of business. Adding to the uncertainty was doubt over the constitutionality of the bill. This uncertainty was resolved in I935 when the Supreme Court struck down the NIRA in Schechter Poultry Corp. $v$. United States. The ruling of the NIRA as unconstitutional on 27 May I935 would seem to return the American economy to a more familiar regulatory framework. If the regime uncertainty hypothesis were correct, uncertainty, as measured by stock volatility, should decrease as the regulatory regime became more certain. However, no change in large jumps is observable, though that may be because the NIRA had already stopped being effective months before. ${ }^{18}$

The Wagner Act, which was signed into law on 5 July I935, was the high tide for union legislation in American history. This Act constrained employer interference in union activities and encouraged collective bargaining and the right to strike. The number of strikes increased dramatically after the passage of this Act, and it seems plausible that this Act could have increased uncertainty in affected industries. The Revenue Act of 1935 also raised taxes significantly, and was called a 'Soak the Rich' tax. By February I937 the United Auto Workers' strike in Flint, Michigan, had succeeded and the union was recognized by General Motors, a major coup for the labor movement. The Social Security Act, following soon after the Wagner Act's passage on I4 August I935, heralded a major expansion of social spending by the federal government and set the stage for vastly higher tax rates. In June 1936, an Undistributed Profits Tax was imposed, which encouraged businesses to distribute profits as dividends instead of retained earnings. By reducing undistributed profits, this tax made bankruptcy much more likely for firms in trouble as they had fewer cash reserves (Hendricks I936). In his fireside chat of 9 March I937, Roosevelt announced his intention to 'pack' the Supreme Court by adding more judges to the court. This policy would allow the president to appoint judges favorable to the New Deal to the court. This was ultimately unsuccessful, though the attempt was widely viewed as an overreach by the executive.

18 Chicu et al. (2013) find that collusion was significant in the cement industry during the I933-5 period, though Taylor and Klein (2008) find that there was a decline in compliance in 1934, and Krepps (I997) finds that industries subject to industry codes did not have higher mark-ups than those not covered by codes. Indeed, Hugh Johnson, head of the NRA and its major supporter, resigned in failure on I October I934, so serious problems were evident long before the de jure end of the program (Schlesinger 2003a, p. I 59). The NRA was finished for good by 1935. 
Many of these New Deal events are shown in Figure 7. Other than the NIRA's passage none of these events line up with high volatility and jumps, which were vastly reduced from the volatile period of I929-34. While policy uncertainty could absolutely create uncertainty shocks, the evidence doesn't show that policy uncertainty played a large role in the weak recovery. Uncertainty was falling while real GDP growth was growing at record rates while the New Deal was in place, as pointed out by Eggertsson (2010, p. 203). Similarly, Roose (1969, p. 225) argues that given the conservative victories of 1936, the regime uncertainty argument would have predicted a large boom rather than the recession that followed.

Romer (I992) argues that the recovery was not slow, as GDP growth rates were at a record high for peacetime. Also, the focus on the potential for an even stronger New Deal recovery seems misplaced, as the economy effectively reached its trough in March I933 when Roosevelt was inaugurated, and record declines in GDP under Hoover were replaced with record GDP growth rates for peacetime under Roosevelt. This article is the first both to directly address economic uncertainty in the New Deal and to find that the New Deal only generated uncertainty in its early phases through 1934 and not for the rest of the Roosevelt presidency. ${ }^{19}$

It is clear that the devaluation of the dollar in 1933 was enormously beneficial to the American economy. The devaluation increased the value of the monetary gold stock, encouraged an inflow of gold from abroad and caused the price level to shoot up. Romer (I992) finds that stimulative monetary policy alone essentially explains the recovery from the Great Depression and Temin and Wigmore (I990) frame the devaluation as a major regime change with significant positive consequences. Eggertsson (2008) argues that the devaluation fundamentally changed agents' expectations from deflationary to inflationary, due to both the devaluation and Roosevelt's commitment to reflate the price level back to its I926 level. According to Eggertsson, the administration made this commitment credible by increasing real and nominal spending. Indeed, price-level targeting is a 'fool-proof way to exit a liquidity trap according to Svensson (200I), and the American economy did rapidly exit the liquidity trap after this regime change. Building on Eggertsson's analysis, I argue that this policy change had an effect beyond the direct monetary effect. The more important effect was that the increased credibility and commitment of these expansionary monetary policies vastly reduced uncertainty about future demand and profitability. Return volatility fell rapidly to more moderate levels from I933 to I937, after being high during the period when monetary policy was uncertain.

However, it is clear that from the gold standard suspension during the first hundred days, through the new parity of $\$ 35$ per troy ounce of gold under the Gold Reserve Act of I934, there was some uncertainty over the future of the American gold standard. Lewis W. Douglas, Roosevelt's Director of the Bureau of the Budget, minced no

19 This is not to say that the uncertainty hypothesis can be disproven for this period; this is simply one piece of evidence to the contrary of what has been found previously in an evolving literature. 
words in commenting on the suspension of the gold standard, 'This is the end of Western civilization' (Schlesinger 2003a, p. 20I). Conservatives were concerned that these large monetary changes generated much uncertainty, which does find some confirmation in the extreme jumps of this period (Schlesinger 2003a, p. 200).

The recovery of the I930s was not unbroken, as the American economy suffered a second recession between the summer of I937 and the summer of I938. The monetarist argument of Friedman and Schwartz (I97I) posits that monetary policy switched from being expansionary to being sharply contractionary in 1936-7 due to a misplaced fear of inflation, and that this policy change can explain the 1937-8 recession. Keynesian critics like Telser (200I) argue that, as the United States was at the zero lower bound, the banking system had significant excess reserves. This meant that increased reserve requirements could be met easily by reclassifying excess reserves as required reserves without restricting lending. Calomiris et al. (20II) and Park and Horn (2015) find increases in required reserves have little effect on lending, while Cargill and Mayer (2006) find otherwise.

Eggertsson and Pugsley (2006) argue that there is scope for monetary policy through a non-reserve channel, though they do cite the change in reserve policy and other policies like the Treasury's sterilization of gold as contributing to the downturn. For Eggertsson and Pugsley, Roosevelt had a clear policy of reflation and pricelevel targeting at the I 926 price level from I933 to I937. In I937, he was convinced by his advisors that the economy was near recovery. Due to this belief and an inflation rate that was creeping higher, Roosevelt's administration abandoned its commitment to reflation and left policy vague and unclear. By I938, the administration reversed its stance, and committed itself to its previous policy of reflation and price-level targeting at the 1926 price level. These policy changes, based on dates outlined in Eggertsson and Pugsley (2006), show that policy changes that left policy unclear are associated with return jumps and volatility, while changes in policy that were clearly expansionary and more certain in 1938 are associated with lower volatility. I have noted in Figure 7 the period that Eggertsson and Pugsley highlighted as characterizing the 'Mistake of I937', which is also a period when equity returns are very volatile and large jumps are observed.

While the 1937 recession was most likely sparked by monetary policy changes and associated monetary uncertainty, events in I937 through I939 related to the prospect of war in Europe and in the Pacific also generated heightened uncertainty. In retrospect, it may seem that the prospect of war would have been welcome given the record GDP growth of the war years to come. Indeed, the American economy had experienced an economic boom in the late I9Ios during the Great War, especially in agriculture bolstered by agricultural exports. However, this boom led to a postwar surge in inflation and ultimately the painful recession of I920-I. Sentiment was strongly opposed to foreign entanglements in the I920s and I930s, showing that the war was not seen fondly (Lowenthal I98I). Attacks on American shipping had been one of the triggers for the American declaration of war in 1917, and the Neutrality Acts of the I930s made the prospects for international trade 
during the war dire, as discussed in the The Annalist. ${ }^{20}$ Even if the United States remained neutral during the conflict, it could find itself cut off from export markets. The Neutrality Act of 1937 extended the existing embargo on arms to any warring nations, while extending the prohibitions to exclude belligerent ships from US ports. Any trade in non-military material could only occur on a 'cashand-carry' basis, which meant payment had to take place immediately in cash. Any loans to or security exchange with belligerents was also banned (Fellmeth I996).

Roosevelt had followed popular sentiment in supporting neutrality and publicly expressed an aversion to interventionism. His famous 'I hate war' speech of August I936 was one of the more forceful examples of this. However, it is clear that he was supportive of the British side and wished to intervene on behalf of Britain and China in the case of armed conflict. In September I937 Japan bombed major Chinese cities such as Shanghai and the War in the East began in earnest. In response to this, Roosevelt gave his famous Quarantine Speech in October I937. He argued that 'a reign of terror and international lawlessness' by the fascists threatened peaceful nations everywhere. If this violence and war did not stop, other peaceful nations would be forced to act and 'quarantine' this threat. As this was not only a change in policy but an unclear one, observers at the time were not sure what to make of it. While Roosevelt had not officially repudiated neutrality, he did favor the Allies (Maney I998, p. I I4). On I2 December I937, the Japanese airforce bombed and sank the USS Panay in Nanking harbor. While Japan claimed this was accidental, American flags were clearly visible to Japanese pilots. ${ }^{21}$ The business press reported on the connection between these uncertainty shocks and large gyrations in equity markets, e.g. the Annalist reported on stock declines in relation to tensions in Asia, and there was a similar article on uncertainty in the European situation and its relation to stock declines in the United States. ${ }^{22}$

Conditions in Europe had worsened by I937 and I938 as well. On II and I2 March I938, German soldiers invaded and annexed Austria into the Reich in the Anschluss. Emboldened by Allied weakness, Hitler immediately demanded the Sudetenland from Czechoslovakia. As both the USSR and France (and, by extension, potentially the United Kingdom) had treaty commitments to defend Czechoslovakia, tensions were high throughout September I938. This crisis had the potential to set off a general war in Europe. Tensions remained high when Hitler canceled the nonaggression pact with Poland in April I939, which eventually led to the September I939 invasion of Poland, bringing the UK and France into World War II. Stock

20 'On the world economic front: our foreign trade and the Sino-Japanese clash', The Annalist, I7 Sept. 1937.

21 Later research has found that the attack was ordered by hardline elements of the Japanese government to bring the US officially into the war so that American interests could be expelled from China (Perry I969).

22 'Financial markets: tense situation in the Far East starts general decline in prices', The Annalist, 27 Aug. I937; 'Financial markets: European situation sends stocks lower, rails under fire', The Annalist, i 8 March 1937. 
volatility was generally low from I939 through December I94 I with the exception of the fall of France in I940, which appears as a spike in large return jumps. Given the uncertainties that had prevailed in the early I930s, it is perhaps unsurprising that business sentiment was sensitive to uncertainty, as Roose argues in his seminal analysis of the I937-8 recession (Roose I969, p. 219).

\section{IV}

The Great Depression period has been extensively studied by both economists and historians due to its importance both as a macroeconomic event and as a watershed in American history. Previous accounts have focused mainly on monetary, fiscal or policy-related explanations for this unprecedented economic crisis. This article adds to the previous literature on the I929-4I period by outlining major plausible uncertainty shocks in this period. Integrating the well-established connection between stock volatility and uncertainty, and utilizing the Barndorff and Nielsen-Shephard test for bipower variation to identify jumps in returns, this history was connected with economic theory regarding the effect of uncertainty on financial markets.

This article has also made the case that uncertainty shocks can be identified by information from securities markets, and that these uncertainty shocks are concentrated in the recession periods of the I930s. Not only were prices and output falling during this period, but also we can see uncertainty shock events that correspond with these periods of equity volatility and extreme changes in returns as theory would predict. I find, contrary to the existing literature, that New Deal policy changes did not generate large increases in uncertainty, as can be seen by low levels of both overall stock volatility and these discontinuous jumps. Major drivers of both jumps and return volatility during the 1929-33 Great Contraction are primarily banking failures, the breakdown of the gold standard and the threat of an end to capitalism. While uncertainty plays a smaller role in I938, monetary uncertainty and war jitters help explain this uncertain recessionary period as well. The Great Depression was an uncertain period, which can be seen in large and persistent disturbances to equity markets as well as in the economic collapse of that period.

Submitted: 29 May 2015

Revised version submitted: 26 January 2016

Accepted: 9 May 2016

First published online: 26 July 2016

\section{Sources}

The Annalist: A Magazine of Finance, Commerce and Economics. New York: New York Times Co. Commercial and Financial Chronicle

New York Times

Wall Street Journal 


\section{References}

ABEL, A. B., DIXIT, A., EBERLY, J. C. and PINDYCK, R. S. (I996). Options, the value of capital, and investment. Quarterly Journal of Economics, III, pp. 753-77.

ANDERSEN, T. G., DOBREV, D. and SCHAUMBURG, E. (20I2). Jump-robust volatility estimation using nearest neighbor truncation. Journal of Econometrics, I69, pp. 75-93.

ARCHIBALD, R. B. and FELDMAN, D. H. (1998). Investment during the Great Depression: uncertainty and the role of the Smoot-Hawley tariff. Southern Economic Journal, 68, pp. 857-79.

BAKER, S. R. and BLOOM, N. (20I3). Does uncertainty reduce growth? Using disasters as natural experiments. National Bureau of Economic Research Working Paper no. I9475.

BAKER, S. R., BLOOM, N. and. DAVIS, S. J. (2OI5). Measuring economic policy uncertainty. National Bureau of Economic Research Working Paper no. 2 I633.

BARNDORFF-NIELSEN, O. E. and SHEPHARD, N. (2004). Power and bipower variation with stochastic volatility and jumps. Journal of Financial Econometrics, 2, pp. I-37.

BARNDORFF-NIELSEN, O. E. and SHEPHARD, N. (2006). Econometrics of testing for jumps in financial economics using bipower variation. Journal of Financial Econometrics, 4, pp. I-3o.

BERNANKE, B. S. (1983). Irreversibility, uncertainty, and cyclical investment. Quarterly Journal of Economics, 98, pp. 85-106.

BLOOM, N. (2009). The impact of uncertainty shocks. Econometrica, 77, pp. 623-85.

BLOOM, N. (20I3). Fluctuations in uncertainty. National Bureau of Economic Research Working Paper.

BLOOM, N., BOND, S. and VAN REENEN, J. (2007). Uncertainty and investment dynamics. Review of Economic Studies, 74, 39I-4I5.

CABALLERO, R. J. and. PINDYCK, R. S (I996). Uncertainty, investment, and industry evolution. International Economic Review, 37, pp. 64I-62.

CALOMIRIS, C. W., MASON, J. and WHEELOCK, D. (20 I I). Did doubling reserve requirements cause the recession of 1937-I938? A microeconomic approach. National Bureau of Economic Research Working Paper no. I6688.

CARGILL, T. F. and MAYER, T. (2006). The effect of changes in reserve requirements during the I930s: The evidence from nonmember banks. Journal of Economic History, 66, pp. 4I7-32.

CHARLES, A. and DARNÉ, O. (2OI4). Large shocks in the volatility of the Dow Jones Industrial Average index: 1928-20I 3. Journal of Banking \& Finance, 43, pp. I 88-99.

CHICU, M., VICKERS, C. and ZIEBARTH, N. L. (2OI3). Cementing the case for collusion under the National Recovery Administration. Explorations in Economic History, 50, pp. 487-507.

CLAUS, E. and DUNGEY, M. (20I6). Can monetary policy surprises affect the term structure? Journal of Macroeconomics, 47, pp. 68-83.

COGLEY, T. and SAR GENT, T. J. (2008). The market price of risk and the equity premium: a legacy of the Great Depression? Journal of Monetary Economics, 55, pp. 454-76.

COLE, H. L. and OHANIAN, L. E. (I999). The Great Depression in the United States from a neoclassical perspective. Federal Reserve Bank of Minneapolis Quarterly Review, 23, pp. 2-24.

COLE, H. L. and OHANIAN, L. E. (200I). Re-examining the contributions of money and banking shocks to the US Great Depression. NBER Macroeconomics Annual, I5, pp. I83-260.

COLE, H. L. and OHANIAN, L. E. (2004). New Deal policies and the persistence of the Great Depression: a general equilibrium analysis. Journal of Political Economy, II2, pp. 779-8 I6.

COWLEY, M. (I98I). Dream of the Golden Mountains. New York: Penguin Books.

DICKSON, P. and ALLEN, T. B. (2006). The Bonus Army: An American Epic. New York: Walker \& Co.

DIXIT, A. (1992). Investment and hysteresis. Journal of Economic Perspectives, 6, pp. I07-32.

DIXIT, A. (I993). Art of Smooth Pasting. London and New York: Routledge.

DIXIT, A. and GOLDMAN, S. M. (I970). Uncertainty and the demand for liquid assets. Journal of Economic Theory, 2, pp. 368-82.

DIXIT, A. and PINDYCK, R. S. (1994). Investment under Uncertainty. Princeton: Princeton University Press.

DUNGEY, M. and GAJUREL, D. (20I4). Equity market contagion during the global financial crisis: evidence from the world's eight largest economies. Economic Systems, 38, pp. I6I-77. 
DUNGEY, M. and HVOZDYK, L. (2012). Cojumping: evidence from the US Treasury bond and futures markets. Journal of Banking \& Finance, 36, pp. I $563-75$.

DUNGEY, M. and MARTIN, V. L. (2007). Unravelling financial market linkages during crises. Journal of Applied Econometrics, 22, pp. 89-I I9.

DUNGEY, M., MCKENZIE, M. and SMITH, L. V. (2009). Empirical evidence on jumps in the term structure of the US Treasury market. Journal of Empirical Finance, I6, pp. 430-45.

EGGERTSSON, G. B. (2008). Great expectations and the end of the Depression. American Economic Review, 98, pp. I476-I5I6.

EGGERTSSON, G. B. (2010). A reply to Steven Horwitz's Commentary on Great Expectations and the End of the Depression. Econ Journal Watch, 7, pp. I97-204.

EGGERTSSON, G. B. and PUGSLEY, B. (2006). The mistake of I937: a general equilibrium analysis. Monetary and Economic Studies, 24, pp. I 5 I-90.

EICHENGREEN, B. (I988). Did international economic forces cause the Great Depression? Contemporary Economic Policy, 6, pp. 90-I I4.

EICHENGREEN, B. (1996): Golden Fetters: The Gold Standard and the Great Depression, 1919-1939. Oxford: Oxford University Press.

ELLSBERG, D. (I96I). Risk, ambiguity, and the savage axioms. Quarterly Journal of Economics, 75, pp. 643-69.

FELLMETH, A. X. (1996). Divorce waiting to happen: Franklin Roosevelt and the law of neutrality, I935-I94I. Buffalo Journal of International Law, 3, pp. 4I3-54I.

FERDERER, J. P. and ZALEWSKI, D. A. (I999). To raise the golden anchor? Financial crises and uncertainty during the Great Depression. Journal of Economic History, 59 (3), pp. 624-58.

FRIEDMAN, M. and SCHWARTZ, A. J. (I97I) A Monetary History of the United States, 1867-1960. Princeton, NJ: Princeton University Press.

HAMILTON, J. D. (1987). Monetary factors in the Great Depression. Journal of Monetary Economics, I9, pp. I $45-69$.

HAMILTON, J. D. (I992). Was the deflation during the Great Depression anticipated? Evidence from the commodity futures market. American Economic Review, 82, pp. I 57-78.

HENDRICKS, H. (1936). The surtax on undistributed profits of corporations. Yale Law Journal, 46, pp. I9-5I.

HIGGS, R. (I997). Regime uncertainty: why the Great Depression lasted so long and why prosperity resumed after the war. Independent Institute Working Paper.

HOOVER, H. (I93 I). Letter to George Harrison, Federal Reserve Bank of New York. 5 October.

HOOVER, H. (1952) Memoirs: The Great Depression, 1929-1941, vol. 3. New York: Macmillan.

ILUT, C. L. and SCHNEIDER, M. (20I4). Ambiguous business cycles. American Economic Review, I04, pp. 2368-99.

KNIGHT, F. H. (20I2). Risk, Uncertainty and Profit. New York: Courier Corporation.

KOU, S. G. (2002). A jump-diffusion model for option pricing. Management Science, 48, pp. Io86-Io I.

KREPPS, M. B. (1997). Another look at the impact of the National Industrial Recovery Act on cartel formation and maintenance costs. Review of Economics and Statistics, 79, pp. I I I-4.

LEE, S. S. and. MYKLAND, P. A (2008). Jumps in financial markets: a new nonparametric test and jump dynamics. Review of Financial Studies, 2I, pp. 2535-63.

LISIO, D. J. (I967). A blunder becomes catastrophe: Hoover, the legion, and the bonus army. Wisconsin Magazine of History, 5I, pp. 37-50.

LOWENTHAL, M. M. (I98I). Roosevelt and the coming of the war: the search for United States policy I937-42. Journal of Contemporary History, I6, pp. 4I3-40.

MAHEU, J. M. and MCCURDY, T. H. (2004). News arrival, jump dynamics, and volatility components for individual stock returns. Journal of Finance, 59, pp. 755-93.

MAJD, S. and PINDYCK, R. S. (1987). Time to build, option value, and investment decisions. Journal of Financial Economics, 18, pp. 7-27.

MANCINI, C. and RENOO, R. (2OI I). Threshold estimation of Markov models with jumps and interest rate modeling. Journal of Econometrics, I60, pp. 77-92.

MANEY, P. J. (1998). The Roosevelt Presence: The Life and Legacy of FDR. Berkeley: University of California Press. 
MCDONALD, R. and SIEGEL, D. (I986). The value of waiting to invest. Quarterly Journal of Economics, IOI, pp. 707-27.

MERTON, R. C. (I976). Option pricing when underlying stock returns are discontinuous. Journal of Financial Economics, 3, I25-44.

MERTON, R. C (I985). On the current state of the stock market rationality hypothesis. Massachusetts Institute of Technology Working Paper.

MOURÈ, K. (2002). The Gold Standard Illusion: France, the Bank of France, and the International Gold Standard, 1914-1939. Oxford: Oxford University Press.

OFFICER, R. R. (I973). The variability of the market factor of the New York Stock Exchange. Journal of Business, 46, pp. 434-53.

PARK, H. and HORN, P. (2015). Did the reserve requirement increases of I936-37 reduce bank lending? Evidence from a quasi-experiment. Journal of Money, Credit and Banking, 47, pp. 79I-8 I8.

PERRY, H. D. (I969). The Panay Incident: Prelude to Pearl Harbor. New York: Macmillan.

PINDYCK, R. S. (I988). Irreversible investment, capacity choice, and the value of the firm. American Economic Review, 78, pp. 969-85.

PINDYCK, R. S (I99I). Irreversibility, uncertainty, and investment. Journal of Economic Literature, 29, pp. IIIO-I 8 .

PINDYCK, R. S (I993). Investments of uncertain cost. Journal of Financial Economics, 34, pp. 53-76.

ROMER, C. D. (I990). The great crash and the onset of the Great Depression. Quarterly Journal of Economics, I05, pp. 597-624.

ROMER, C. D. (I992). What ended the Great Depression? Journal of Economic History, 52, pp. 757-84.

ROOSE, K. D. (I969). The Economics of Recession and Revival. Hamden, CT: Archon Books.

SCHLESINGER, A. M. (2003a). The Coming of the New Deal, 1933-1935. New York: Mariner Books.

SCHLESINGER, A. M. (2003b). The Politics of Upheaval, 1935-1936. New York: Mariner Books.

SCHWERT, G. W. (I989). Business cycles, financial crises, and stock volatility. Carnegie-Rochester Conference Series on Public Policy, 3I, pp. 83-I25.

SVENSSON, L. E. (200I). The zero bound in an open economy: a foolproof way of escaping from a liquidity trap. Monetary and Economic Studies, I9, pp. 277-3 I2.

TAYLOR, J. E. and KLEIN, P. G. (2008). An anatomy of a cartel: the national industrial recovery act of I933 and the compliance crisis of I934. Research in Economic History, 26, pp. 235-7I.

TELSER, L. G. (200I). Higher member bank reserve ratios in I936 and I937 did not cause the relapse into depression. Journal of Post Keynesian Economics, 24, pp. 205-I6.

TEMIN, P. and WIGMORE, B. A. (I990). The end of one big deflation. Explorations in Economic History, 27, 483-502.

VAVRA, J. S. (2013). Inflation dynamics and time-varying volatility: new evidence and an S's interpretation. National Bureau of Economic Research Working Paper no. I9I 48.

VERONESI, P. (I999). Stock market overreactions to bad news in good times: a rational expectations equilibrium model. Review of Financial Studies, I2, pp. 975-1007.

VOTH, H.-J. (2002). Stock price volatility and political uncertainty: evidence from the interwar period. Massachusetts Institute of Technology Working Paper.

WICKER, E. (I97I). Roosevelt's I933 monetary experiment. Journal of American History, 57, pp. 864-79. WICKER, E. (200I). The Banking Panics of the Great Depression. Cambridge: Cambridge University Press. 